\title{
The Grammar of Hegemony
}

\section{Peter Ives $^{1}$}

I feel that if language is understood as an element of culture, and thus of general history, a key manifestation of the 'nationality' and 'popularity' of intellectuals, [the history of the Italian language] is not pointless and merely erudite.

-Antonio Gramsci ${ }^{2}$

\section{The Language Problem}

Like nationalism and consciousness, language is a topic that troubles Marxism and divides its self-proclaimed adherents. While some argue that social historians made the so-called 'linguistic turn' relatively late, ${ }^{3}$ the controversy caused by Gareth Stedman Jones' Languages of Class (1983) has been followed throughout the 1980s and 90 s by explicit concerns over language and its relation to Marxism. ${ }^{4}$ These debates contain a polemic about the nature of language epitomized in the example of the brothers Anderson, Perry and Benedict.

In his grievous critique of structuralism and post-structuralism, Perry Anderson contends that language is different from all other social institutions and, thus, structuralist linguistics cannot provide a paradigm for other disciplines. He argues that language is unique because, among other reasons, it is "axiomatically individual" in contrast to collective structures such as nations, classes, or generations. ${ }^{5}$ This contention is in direct opposition to that of his brother, Benedict Anderson, who states emphatically that "the most important thing about language is its capacity for generating imagined communities, building in effect particular solidarities." 6 The tension here is related to the distinction made by the founder of structuralist linguistics, Ferdinand de Saussure, between langue (langauge as a static, system of signs defined in relation to each other) and parole (spoken or written usage of this system of language). ${ }^{7}$ What is at stake, then, is the relationship between agency and structure.

Within social history, these different perspectives each have their supporters. Bryan Palmer, to cite just one example, sides with Perry Anderson's argument that structuralist methods for studying language cannot be applied to other social institutions because of language's exceptional characteristics. ${ }^{8} \mathrm{He}$ vociferously attacks the primacy of language and the emphasis on language as a 


\section{Left History 5.1}

system of signs that do not derive their meaning from reference to the 'real,' non-linguistic world. On the other side, Patrick Joyce's Democratic Subjects provides one recent example of social history that embraces language as that which constructs social subjects. ${ }^{9}$

It is difficult to approach these issues without dealing with epistemological questions about the possibility of knowledge of the 'real' world that language is or is not supposed to reflect. Yet, to open these questions one would have to deal with the long history of relativism and Marxism of which the 'linguistic turn' is just a recent manifestation. Here it is perhaps best to side-step this issue with a quote from Antonio Gramsci. Discussing attacks against relativism as it appeared in the 1930s, he wrote:

The entire polemic against the subjectivist conception of reality, with the 'fearsome' question of the 'objective reality of the external world,' is badly framed and conducted worse and is to a great extent futile and superfluous. ${ }^{10}$

Perhaps this assessment applies also to some of the debates about the relativist dangers of language for Marxism in the 1990s.

While these epistemological questions cannot be entirely avoided, I will limit myself to the problems of how the individual agency involved in expression relates to the view of language as a system of self-referential signs not moored to some outside, non-linguistic reality. ${ }^{11} \mathrm{I}$ am not suggesting that it is impossible, or even difficult, to reconcile the two factors: first, that language is spoken by individuals to express their personal thoughts and feelings; and second, that language is a communal structure. This communal nature of language requires that other people speak the same language for individuals to communicate successfully. This linguistic structure is handed down to us from previous generations.

The reconciliation between these two factors has been one of the main components of philosophies of language and linguistics at least since Wilhelm von Humboldt's Linguistic Variability (1836). What I will suggest is that there are various ways to make this reconciliation. The differences among these methods are especially important to Marxism as a political project. The failure to take both communal and individual aspects of language into account combined with the pitting of Marxism against structuralism and post-structuralism is just one extreme indication of a whole quagmire surrounding Marxist considerations of language. It shows how the polemics against structuralism and post-structuralism have led, at least in some circles, to very odd and - dare I say - anti-materialist, propositions about language. ${ }^{12}$ 
In addition to overt attacks against post-structuralism in the name of Marxism, other Left traditions of social theory declare that there is a tension between Marxist philosophy and language. Jürgen Habermas and Pierre Bourdieu, for example, part company from 'traditional' Marxism substantially due to their assessment that Marx's framework is not adequate for explaining linguistic or symbolic interaction. They both attempt to augment Marxism with some additional theory of communication. ${ }^{13}$

In order to address a few strands of the conflicted relationship between Marxism and language, this paper will turn to the work of Antonio Gramsci and his response to the linguistic unification of Italy. This will provide an approach to language that - far from parting company with Marx's writings - is selfconsciously a development of Marxist political theory. Moreover, it places great emphasis on language as a model for understanding political forces in society. And yet, Gramsci rejects not only the contention that language is axiomatically individual, but moreover he subverts the traditional presumptions of language merely as a vehicle of human agency or expression of intention. ${ }^{14}$ These presumptions constitute the mainstays of critiques of the so-called 'linguistic turn.'

Before considering the Italian case, it is important to assert that the question of language and Marxism pre-dates the so-called 'linguistic turn' (or its post facto construction) and the supposed advent of post-modernism or post-structuralism. It is too simplistic and misleading to think of language as a topic that comes into view only with Saussurean linguistics. This view not only distorts Saussure's work, ${ }^{15}$ as is so often the case when he is viewed from outside the tradition of linguistics, but it misrepresents the role of language in social theory before structuralism. For a whole host of commentators, language has been elided with structuralism, confusing what is at stake in both.

\section{Language and Nation}

Well before structuralism's particular emphasis on the systematic nature of language, the idea of language as a communal institution intermingled with ideas about individuals using language. The connection between language and nation at the heart of German Romanticism is often attributed to Johann Gottfried Herder. ${ }^{16}$ This is an important connection because, as Benedict Anderson's work shows, it is one particular understanding of the relationship between the individual and the communal aspect of language. Here the communal aspect is a national one. Benedict Anderson's Imagined Communities is in some senses an argument about how languages that had once been organized 
around religious, dynastic and imperial forces came to be based upon 'national' communities or nation-states.

This is important to my argument because it highlights how the 'common sense' connection between language and nation or 'one's people' is a historical one. That Frederick the Great spoke French was, at one point, perfectly normal for a German prince. ${ }^{17}$ In most of Europe, before the fall of Latin as the 'official' language, the relation between a person's language and the place they lived, the community in which they were imbedded, was far from 'natural, 'obvious' or 'automatic.' Our current conceptions of nation and community are historically dependent on the shift of vernacular languages into every realm of life, including art, literature and politics, that had been deemed the realm of Latin in Europe before the fifteenth century. ${ }^{18}$

Many scholars have documented the role of language 'standardization' in the process of nation building. ${ }^{19}$ And yet, while nation building involves the diffusion and control of language, there are over two thousand languages in the world with some form of written literature (and many more purely oral languages) and less than two hundred nation-states. In addition, many different nation-states share a single language such as England, the United States and Canada.

Moreover, there are particular examples directly contrary to the languagenation equation. In Ireland at the beginning of the nineteenth century, British Protestants were the primary advocates of the Irish language concerned with vernacular access to the Bible. In contrast, the Irish nationalists favoured the practicalities of teaching English in the school system. ${ }^{20}$ These counter-examples notwithstanding, most 'nationalist' movements involve, to a greater or lesser extent, some recourse to a language that unites a people and justifies national autonomy.

\section{Early Versions of the Arbitrary Sign}

Before the advent of Marxism, emphasis on the communal nature of language was in tension with language viewed as a tool for individual expression of preformed interests, thoughts and feelings. These debates have been repeated in various forms at least since the German Romantics rejected John Locke's theory of language. In An Essay Concerning Human Understanding (1693), Locke articulate a radical argument that all signs or words in human language are arbitrary. That is, there is no characteristic in the word itself (spoken or written) that connects it to its meaning. The relation between what Saussure calls the signifier and its signified is due, according to Locke, only to historical convention. ${ }^{21} \mathrm{He}$ 
followed Hobbes and Bacon in arguing that words do not represent things or objects in the real world, but rather they represent ideas. ${ }^{22}$ Yet, both concepts linguistic arbitrariness and words primarily signifying ideas rather than objects - are often ascribed to Saussure and the supposed 'linguistic turn' by both its critics and adherents.

Unlike previous thinkers, Locke was concerned with the inherent problems in language's ability to convey ideas from one individual to another. Locke argued that words are arbitrary, but that the imposition of a given meaning on a given sign is an individual, and not a communal, act. ${ }^{23}$ Thus, the imperfection in language is due to the difficulty in knowing whether two people are using a word to signify the exact same idea. For simple communication this is not an insurmountable problem. A word's meaning can be verified easily with reference to an object for which the idea stands. But with complex ideas such as 'justice' there is virtually no method for setting a standard. While Locke argues such problems cannot be totally overcome, he emphasizes that they can be minimized by defining terms carefully and using them consistently. ${ }^{24}$

The German Romanticists rejected Locke's view of language as purely an (imperfect) instrument for transmitting ideas from one individual to another. Most specifically, they rejected the notion that these ideas were formed outside and prior to language. With great interest in Rousseau's wrestling with language as an instrumental medium arising out of utility versus language as an expression of emotion and spirit arising out of passion, the German Romanticists swung the emphasis in the study of language onto that poetic element. They saw language as the aesthetic or artistic expression of the speaker or the group of speakers to which the language belonged. With his influential argument that the origin of language was neither divine nor natural but distinctly human, Herder emphasized the connection between human languages and the nations where they were spoken. ${ }^{25}$ If language is created by God or is of natural origin, it follows that the differences among languages are superficial or can be reduced to more basic non-human bases. But if, as Herder argued, language is a human creation, then the differences among languages can be as diverse as human communities.

This move in philology was parallel to a shift in emphasis from the classical languages of Latin, Greek, and Hebrew to a new valorization of the study of vernacular languages in their own right. For example, the older arguments that Italian vernaculars were just imperfect and degenerate versions of Latin gave way to the acceptance of specific mother tongues as important precisely because of their role in creation and expression. Central in what Lia Formigari has described as the transition from the empirical to the transcendental theories of language is Wilhelm von Humboldt. ${ }^{26}$ 


\section{Left History 5.1}

\section{Humboldt's Reconciliation}

Humboldt reconciled the individual-structural or communal tension in language by distinguishing what he called energia, the inner linguistic sense and spontaneous expression of people (as both individuals and collectives) from ergon, the outer sound produced and the result of past energia which had been passed down from previous generations. Humboldt described his conception as the synthesis of two opposing views on language, one close to the Lockean view, and the other the Romantic version:

The two mutually opposing viewpoints, one which sees language as alien and the other which sees it pertaining to the soul, one which sees language as independent of the soul and the other which sees it dependent upon it, are really combined in language and constitute the idiosyncrasy of its nature. This conflict of ideas, moreover, must not be solved so that language becomes in part alien and independent and in part neither. Language is objectively reactive and independent precisely to the extent that it is subjectively reacted upon and dependent. ${ }^{27}$

In this way, he combined philological analysis of dead and living languages with an idealist emphasis on the creative capacity of individuals and communities to use and reshape languages. He aimed to couple the Romanticist ideas of aesthetic creation with empirical research on global varieties of languages that aroused great interest in philology.

From this perspective, Humboldt provided a conception of language that underlies Noam Chomsky's linguistics and much of common sense notions of language and free speech. If Marxists are going to engage in debates over language theory, it is this view of language that we must confront. Its purchase on public consciousness has been far greater than any version of so-called postmodernism. And it is this view of language that obscures explanations of how 'interests,' including class interests, are formed and articulated within and not prior to language.

Humboldt argued that language is generative because an infinite number of new and meaningful sentences can be produced from a finite number of rules. Sentences, even if never previously uttered, can be recognized as well-formed English sentences, grammatically incorrect English sentences, or meaningful French sentences. This is how the creative capacity of energia can be expressed even given the fixed and finite structures of a particular language, that is from ergon. Chomsky's mathematical proofs that a finite set of grammatical rules can generate an infinite number of new meaningful sentences gave rise to the whole 
enterprise of generative grammars that he himself attributes theoretically to Humboldt. 28

Humboldt synthesized the creative individuality and communal structure of language with the theory of energia and ergon. It is perhaps the most influential method in linguistics for thinking about the tension between rupture and continuity or revolution and tradition. This synthesis between creative innovation and the passing-down of traditional structure is made in terms of 'inner' thought and 'external' language. The creativity of 'inner' thought is expressed through 'external' language structures passed down from previous generations. It is precisely this process that liberates the inner creativity giving it life and allowing it expression. While Humboldt insists that these 'inner' and 'outer' aspects of language constitute an indivisible unit, and that their indivisibility is akin to their human quality, this indivisible unit is still driven by the priority given to the internal element of intellectual power. This synthesis relies on the metaphors of the 'depth' and 'internality' of the soul against (or moving towards) the 'surface' and 'externality' of language structure. While the nation or community is placed on the 'deep' side of this divide, the framework remains dichotomous and asymmetrical.

Humboldt's Linguistic Variability was published posthumously the year that Karl Marx began university in Berlin, before the advent of any Marxism. I think it is fair to say that Marx and Engels' episodic comments on language do not amount to any substantial position on the topic. But neither do I think their statements constitute a substantial position on language around which the likes of Bourdieu and Habermas must step. Of course, Marx's philosophical framework has implications for this topic and it is upon that ground that Habermas, Bourdieu and many others have tried to overcome Marx's perceived lack. I do not wish to re-tread that ground, but take a different route. Looking at Gramsci and the questione della lingua can shed light on issues that other Marxist considerations on language obscure.

\section{Gramsci's Linguistics}

Although neglected in much of the secondary literature, Gramsci studied linguistics at the University of Turin. ${ }^{29}$ Being Sardinian, Gramsci was an asset to his linguistic professor, Matteo Bartoli, who was conducting research on Sardinian language. Bartoli polemicized against Leipzig's Neogrammarian school that represented the height of comparative historical linguistics. Ferdinand de Saussure, the founder of structuralist linguistics, emerged and distinguished himself from the Neogrammarians. Thus, Gramsci was immersed 


\section{Left History 5.1}

in the same context of European linguistics from which structuralist linguistics arose. Before devoting his life to the communist struggle, entering parliament, or being imprisoned by the fascists, Gramsci proposed writing a dissertation on the history of the Italian language. As Franco LoPiparo has argued persuasively, Gramsci derived many of his key ideas and concepts from turn of the century Italian linguistics, most notably the concept of 'hegemony. ${ }^{30}$

Gramsci's approach to language undermines Humboldt's view of linguistic expression progressing from the internal depths of human will (individual or collective) towards the outer, surface realm of social interaction. Instead, Gramsci's focus on the interaction of various languages provides what the proponents of the 'linguistic turn' in social history find attractive in the work of Derrida or Foucault. Stedman Jones mobilizes the concept of language as a system of self-referential signs in order to analyze the Chartist movement. His major concern is to avoid presuming that these discourses of Chartism are merely the linguistic expression of what Marxist analysis of the social context presents as the participants' interests. ${ }^{31}$ Gramsci's approach provides the theoretical perspective for precisely this type of analysis. ${ }^{32}$ While Laclau and Mouffe chastise Gramsci for reducing class consciousness to the economic base, ${ }^{33}$ a focus on his writings on language as well as his analysis of Italian history illuminates his argument around the incomplete and hence ultimately unsuccessful development of the Italian proletariat leading up to 1919-20. Gramsci takes economic factors into account, but not as determinate causes outside the realm of language. On the contrary he does not erect barriers from academic abstractions between linguistic and other types of human activity. For an appreciation of this aspect of Gramsci's work, some context of the role of language in Italian society is crucial.

\section{La Questione della Lingua}

When Italy was politically unified in 1861 , la questione della lingua had a long involved history explicitly tied up with the creation of Italy. On one hand, the Italian nation-state could be seen as the political fulfilment of Dante's cultural vision or the culmination of the appearance of italia and italiano in the thirteenth century. But, as the popularity of the Northern League today shows, this unification is far from settled. As Gramsci insisted, the reality was (and remains) that the separation between the general population and cultured elite, bemoaned by Dante, was (and is) as present as ever. ${ }^{34}$

Tullio DeMauro estimates that only two and a half percent of the Italian population spoke 'standard' Italian in $1861 .^{35}$ Before unification, la questione 
della lingua was an erudite debate that had little effect on the vast majority of Italians. But these debates became the basis for governmental policy affecting the daily life of every Italian. La questione della lingua became an urgent social and political problem intricately connected with the success or failure of the new nation-state. The lack of an Italian language was seen as a problem whether one held Locke's view that language was solely an instrument of communication or if one drew Herder's connection between language and nation.

Alessandro Manzoni, author of the classic novel, I pronessi sposi [The Betrothed], is central to Italian linguistic unification. In addition to shifting the terms of linguistic debate in Italian literature by writing I promessi sposi in contemporary bourgeois Florentine instead of the classic literary language, Manzoni became influential in creating government language policy. He made his literary practices into explicit linguistic arguments, rejecting previous approaches to Italian language that had focused on the beautiful, unchanging languages of literature. Instead, both literature and national policy, according to Manzoni, require the study of everyday language use.

Along with Manzoni's general pro-Tuscan stance, this perspective had a significant impact. Six years after unification, Manzoni was appointed to oversee a government commission on the most effective way to unify the Italian language and spread it throughout Italy. Manzoni's solution was to adopt Tuscan as the 'standard' Italian, recruit school teachers from Tuscany, and disperse them around Italy and create dictionaries and grammars.

Manzoni's approach was criticized by the linguistic historian Graziadio Ascoli. Ascoli argued that Manzoni's plan would result in an artificial unity imposed extrinsically upon the Italian people. In the debates of the $1870 \mathrm{~s}$, Ascoli argued that Italy's problems of linguistic unity were due to a terrible gap between the intellectuals and the people. Fifty years later, in the pages of $l l$ Grido del Popolo, Gramsci repeated Ascoli's argument that the merely formal solution of artificial imposition could not solve such an entrenched historical and political problem ${ }^{36}$ Of course, Gramsci developed this diagnosis into one of his major themes.

Gramsci's initial articulation of this argument took place within the framework of his opposition to Esperanto. Some members suggested that the Milan section of the Socialist Party should adopt Esperanto. But Gramsci argued that this was comparable to Manzoni's solution to the langauge question. One might expect Gramsci to favour Manzoni with his turn away from praise of 'dead' languages and his active participation in attempting to spread 'standard' Italian to all strata of Italian society, and explicitly the peasantry and working classes. But instead, Gramsci equated Manzoni's solution with Esperanto. ${ }^{37}$ 


\section{Left History 5.1}

Gramsci argued, using Ascoli's historical linguistics as evidence, that "not even a national language can be created artificially, by order of the state." ${ }^{38}$ And yet Gramsei was very much aware of the problems created by the lack of an Italian language. He attacked Gentile's education act of 1923 because it did not teach standard Italian grammar in the elementary schools. And in his last prison notebook, he argued that "it is rational to collaborate practically and willingly to welcome everything that may serve to create a common national language, the non-existence of which creates friction particularly in the popular masses." 39

Gramsci's comparison of Esperanto and Manzoni's approach is interesting precisely because the former represents a sort of Lockean view of language. Esperanto, an 'artificial' language, is based on the idea that language is merely an instrument of communication. Manzoni, on the other hand, was seen as one of the foremost representatives of Romanticism in Italy in the nineteenth century. ${ }^{40}$ It was the living soul of the Florentine language that inspired Manzoni.

Gramsci argued that "Esperanto, the single language, is nothing but a vain idea, an illusion of cosmopolitan, humanitarian, democratic mentalities which have not yet been made fertile and been shaken by historical critical thinking." 41 If Esperanto's utopian vision had not been put to the test of history, Manzoni's certainly had. While Gramsci argued that in the end elementary-school teachers were not recruited exclusively from Tuscany and that Manzoni's dictionary was never finished, Manzoni's language policy had quite a profound effect. ${ }^{42}$ Many schools actively taught Manzoni's principles. And partially due to Manzoni's influence, universities stopped teaching 'eloquence' and started teaching the critical study of literature. ${ }^{43}$

Gramsci was correct in recognizing that many specific Manzonian proposals were not adopted, and that institutions such as the military and the radio ultimately played a larger role in spreading the national language than did Tuscan school teachers. ${ }^{44}$ But a substantially 'Tuscan' standard was created and diffused. It was able to absorb many other dialects' words and phrases and became 'Italian." 45 So, on one level, Gramsci's equation of Esperanto with Manzonianism was a rhetorical move to condemn them both. It deflated the supposedly 'radical' solution of Esperanto comparing it with a status-quo policy that had not been terribly effective. Gramsci simultaneously inflated the extent to which Manzoni's Tuscan was an artificial construct and not a living language at least for anyone outside of Florentine's bourgeoisie.

But on another level, Gramsci was correct that the questione della lingua was intricately connected with the problem of Italian unity and nation. This problem was rooted in the role of intellectuals within society, and the prepon- 
derance of traditional intellectuals who are quite distinct from the masses as opposed to organic intellectuals who are more integrated. Even today, much of the rhetoric of the Northern Leagues relies on an 'othering' of southern Italy in which foreignness of southern dialects and Sicilian language is employed. In comparison to the minute number of Italians who spoke 'Italian' in 1861, the standard 'Italian' has been very successful. Whether in the use of dialect in neorealist film of the post-World War Two era or Pier Paolo Passolini's explicit connection between dialect and progressive populism in what he labelled 'nuove questioni linguistiche' [new language questions] in the 1960s, Italians, Left and Right, have concerned themselves with the language question as a manifestation of the relationships among intellectuals, the people and culture.

\section{Rejecting the Linguistic 'Substratum'}

Much of the methodology and historical evidence of Gramsci's critique of Manzoni's solution and Esperanto was taken from Ascoli and Bartoli. Ascoli's major theoretical construct (at least in his later writings) was the concept of the 'linguistic substratum.' He argued that whenever two or more languages came into contact there was always a conflict and a reaction of one language on the other. When one language succeeded in replacing the other, there remained a 'substratum,' an underlying memory of the previous language, that continued to exert pressure on the 'victorious' language. Ascoli used this concept to explain the shifts in language that the Neogrammarians explained through 'laws' purely internal to the language in which change occurs. He showed that many historical linguistic changes had been caused by the 'linguistic substratum' of the region's people.

This led Ascoli and Gramsci to argue that Manzoni's solution could not succeed because it neglected the inevitable conflict that would result from the persistence of the pressures of the 'linguistic substratum.' Where Gramsci, and Bartoli before him, part company with Ascoli, is the extent to which Ascoli saw this 'linguistic substratum' as not only socio-historical but also, to a large degree, biological and physiological. Ascoli tried to combine the naturalistic differences between speakers with the habituation of how they learn to speak and reproduce sounds. ${ }^{46}$ Bartoli and Gramsci were very critical of Ascoli's biologism. They saw it as the influence of positivism. Gramsci compared such mechanical abstraction to the economistic Marxism of the Second International. Moreover, Ascoli's 'substratum' argument replicated, in a different form, Humboldt's concepts of linguistic depth, a soul of the people that was transformed into a surface or directly observable aspects of everyday speech. Ascoli 


\section{Left History 5.1}

and Humboldt privileged this linguistic depth and decried situations where the superficial or surface structures impede or distort the inner depths. Both argued that the surface structures of actual speech should, for moral and pragmatic reasons, follow from and adapt to these deeper, older linguistic forms.

In rejecting both the terminology of the 'substratum,' and especially its naturalistic and positivistic residues, Gramsci replaced the deep/surface metaphor and the privileges that it maintained. It was this rejection and his replacement of it that make Gramsci crucially relevant to the role of language in social theory at the end of the twentieth century. Without fully embracing a notion of the 'death of the author,' Gramsci critiqued what Derrida calls 'full presence' or 'representation' in language..$^{47}$ Gramsci understood that it is only within the structures of language that subjects define their interests and make decisions about what they want, and what they speak and write about. His position not only challenges the defenders of Marxism against the so-called linguistic turn, it also provides an example of a Marxist approach to language occluded by the proponents of the linguistic approach. Where Patrick Joyce and Gareth Stedman Jones agree with Bryan Palmer and Perry Anderson is that Marxism is incompatible with the 'linguistic approach.' Gramsci's writings are more akin to Marc Steinberg's argument that it is possible (and preferable) for cultural Marxism to be both materialist and discursive. ${ }^{48}$

\section{The Grammars of Hegemony}

Gramsci replaced the idea of a 'linguistic substratum' with what he called 'spontaneous grammar.' Gramsci defined 'spontaneous grammar' or 'immanent grammar' as the grammar of a language that one follows when speaking but without knowing or being conscious of it. Individual expression, then, always takes place within at least one grammar, if not more, and however 'spontaneous' that grammar is, it structured what is being expressed. As Gramsci explained, "An individual is historically original when he gives maximum prominence to social being, without which he would be an 'idiot' (in the etymological sense, which is however not far from the common and vulgar sense)." from the Greek idios meaning private or own's own, from which 'idiom' is also derived ${ }^{50}$ But this tension between individual originality, idiosyncracy and novelty and sociality, conformism and adherence to the past, (i.e. what Humboldt sees as energia and ergon) is augmented by what Gramsci called 'normative' grammar, adapting a term common in linguistics since the Port Royal grammars in 1660.

Spontaneous grammar is distinguishable but not totally separate from 
'normative grammar.' Gramsci defined normative grammar as being made up of "reciprocal monitoring, reciprocal teaching and reciprocal 'censorship' expressed in such questions as 'What did you mean to say?', 'What do you mean?', 'Make yourself clearer,' etc., and in mimicry and teasing." grammar includes the written grammar as taught from textbooks and when language is taught as a foreign language as well as the more informal, not necessarily written, 'conformism' which establishes judgements of the correctness or incorrectness of speech. For Gramsci, it was normative grammar that was forced upon people, whether the language is Tuscan, Esperanto, or Sardinian. However, this imposition of a normative grammar is not always negative or regressive.

In the same way that Gramsci's 'hegemony' was an investigation into how force and consent are combined, so the relationship between spontaneous and normative grammars is not one of opposition, just as for Gramsci 'coercion' is not the opposite of 'consent.' In one of Gramsci's most succinct statements, he drew out this point: "Coercion is such only for those who reject it, not for those who accept it. One can say of coercion what the religious say of predestination: for the 'willing' it is not predestination, but free will., 52 In the same way, normative grammar is not necessarily an immoral imposition of force, but is at times necessary. Likewise, spontaneous grammar is never totally free of coercion, just as consent is not. In fact, spontaneous grammars are nothing other than the historical residues of the imposition of previous normative grammars. As Gramsci stated, pure 'spontaneity' does not exist. "In the 'most spontaneous' movement it is simply the case that the elements of 'conscious leadership' cannot be checked, have left no reliable document." ${ }^{53}$ Thus, Gramsci rejected Humboldt and Ascoli's mostly one sided movement from either energia to ergon, or the substratum to the phenomenal stratum, and argued that the interaction went both ways.

This is why Gramsci favoured the creation of a national language and thus a normative grammar, unlike the Marxist theorist of language Valentin Vološinov. ${ }^{54}$ What he advocated was a national language that was truly national, not a non-national language stretched over the national territory. This later situation, according to Gramsci, contributed to the conditions that allowed for the rise of fascism. The friction created among the various populations, unresolved in the Risorgimento, enabled fascists to propagate an ideology that did not make sense for the peasantry or the working-class, but to which a significant portion of each consented.

Had the Italian intellectuals been able to bridge the gap between themselves and the populace and create what Gramsci called a truly 'national-popular collective will,' and along with it a national unified language, fascist coercion 


\section{Left History 5.1}

might not have been able to garner the degree of consent that it required. Instead, the fascist alliance between the northern industrialists and the southern landowners exploited the divisions within Italian society and languages. Ideologically, this fascist alliance required the non-existence of an effective Italian normative grammar. The philosophical support that they used in this pursuit was not any Manzonian linguistic but another Romanticist influenced tradition, the Idealism of Benedetto Croce and especially Giovanni Gentile.

An aspect of Gramsci's devastating critique of Croce's idealism is that by equating language use with creative self-expression and relegating prescriptive or normative grammar to non-existence, Croce laid the groundwork for fascist ideology. Gentile used Croce's The Aesthetic as the Science of Expression and of the Linguistic in General (1902) to justify the absence of instruction in Italian grammar in the fascist school curricula in the Education Act of 1923. The effect, as Gramsci argued, was to condemn a great number of working-class and peasant children to illiteracy and deny them access to the structures of power.

In opposition to this position, Gramsci distinguished his conceptions of 'normative' and 'spontaneous' grammars from artistic expression. He wrote:

The history of languages is the history of linguistic innovations, but these innovations are not individual (as is the case in art). They are those of a whole social community that has renewed its culture and has 'progressed' historically.

These innovations become part of "the individual as a complete, determinate historical-cultural element." 55 Thus, Gramsci did not solely replace Humboldt's imagery of the unity of creative expression and communally structured language with the terms 'spontaneous grammar' and 'normative grammar.' He does not merely provide Perry Anderson's 'axiomatically individual' language with its obvious communal side. He reformulates the bipolar tension between creative capacity (individual or communal) and language structure with a more complex theorization of the limits and possibilities that speakers have to negotiate among various spontaneous and normative grammars. Examples of this were given by Gramsci in his writings on literature and theatre. He consistently asked: to what extent is the author's expression able to reach and capture the audience? and what does this mean about both audience and author or production?

Gramsci did not create an opposition between spontaneous consensus and forced coercion, but instead formulated a distinction between those normative grammars that truly express - or were successful in creating - a 'national popular collective will' and those that are not successful but instead must be imposed and enforced. That is to say, the normative grammar of a popular unified 
national language is different from an artificial, Manzonian language. The normative grammar was the result of only a 'passive' revolution which existed because of the dis-unity and incoherence of various existing spontaneous grammars. Like the role of the term 'organic' elsewhere in the Prison Notebooks, Gramsci used spontaneous grammar to determine the gradation or the type of normative grammar, or of hegemonic relationship.

The constant pressure on the normative grammar from the underlying spontaneous grammars "creates friction particularly in the popular masses." The practical and moral question then became how to relieve this pressure. My contention is that this is the central question of hegemony and its various uses throughout Gramsci's writings. Its dynamics require examination through what we might now call discourse analysis. Hegemony is the relationship between spontaneous grammars and the prevailing normative grammar. For Gramsci, the goal of the workers' movements, first through the factory councils then through the Communist Party, was to relieve this tension by paying careful attention to the process in which the normative grammar is formed.

Much of the confusion that arises around Gramsci's use of 'hegemony' derives from the fact that he used it in two very different ways. ${ }^{56}$ At times it described the manner in which a normative grammar had been imposed. It shows how friction among various spontaneous grammars remains unresolved but is hidden (for a time) by the imposition of a normative grammar. But Gramsci also suggested the possibility of a 'proletarian' hegemony as an attempt to solve this friction by relieving the tensions among various spontaneous grammars through the creation of a progressive normative grammar.

In the first type of hegemony, the underlying pressure from various spontaneous grammars on the national normative grammar must be relieved, quelled, sedated or repressed if the normative grammar was to remain in power. Of course, there are many strategies that could be used to maintain the power of normative grammar. These include a rigid education system like that proposed by Manzoni, as well as overt military control. Another strategy by which a normative grammar could retain its hegemony, although not mutually exclusive from Manzoni's, is if its rules and mechanisms are relatively unknown outside the dominant class. This would be the outcome of Gentile's educational reforms. Such strategies are more likely to be successful if the normative grammar has little organized opposition and the pressure against it is to some extent counteracted by the different forces among the various spontaneous grammars. But the consequences of such a situation were morally and practically troubling to Gramsci.

To oppose these 'regressive' hegemonies, Gramsci proposed the creation of 
a normative grammar that had a different and more conscious relationship to the spontaneous grammars that constituted it. He argued that all normative grammars were the (supposed) "exemplary phase[s]" that have been frozen and defended as the "only" grammar worthy of becoming a 'common' language. He, thus, rejected any attempt to impose normative grammar whether it was the normative grammar of Esperanto, or some specific dialect like Florentine. Instead, he proposed the more ethical and pragmatic development of normative grammar that did not have to manage this friction but was itself the product of resolving it. The process was very similar to Gramsci's description of how 'common sense,' as a disconnected, contradictory and confusing melange of beliefs and ideas, could be moulded into 'good sense' and then into a philosophy of praxis. This process occures both in civil society and within the apparatuses of the state. It is the creation of a 'popular collective will.' The extent to which no one was able to mould such a 'popular collective will' permited (and indeed required, in that no alternative was available) the imposition of a worldview or normative grammar of a particular social group (in this historical instance the bourgeoisie) on the entire Italian population. ${ }^{57}$

I am not suggesting that Gramsci provided a fully articulated, all-encompassing theory of language. But his theory of language is an integral part of his Marxism and political activism. This suggests at least one possibility of a Marxist theory of symbolic interaction that does not require Habermas or Bourdieu's augmentation of Marx's concept of labour with some other concept of communication. Moreover, his theory of language is fully compatible with "the primacy of language stressing its nonreferential and its determinative capacity" 58 of post-structuralism condemned by Palmer and Perry Anderson in the name of Marxism. Perhaps more importantly, given the much greater command that Chomskian linguistics has in today's world, Gramsci's theory of language transcends the Humboldtian dichotomy between linguistic creativity and language structure. It also suggests that the current political convergence in Italy (and elsewhere) has not superseded many of the tensions that plagued Italy's past.

'I would like to thank Victoria Heftler for her continued help with this paper and for organizing the panel from which it developed, "Tools for Constructing Membership" presented to the Society for Socialist Studies at the Learned Societies Congress, June 1997, St. John's, Newfoundland. I would also like to thank the other panelists, Rob Heynen, Dennis Soron, Jeremy Stolow, and the S.S.H.R.C. Adele Perry also provided valuable help, for which I am grateful.

${ }^{2}$ Antonio Gramsci, Selections from Cultural Writings, trans. William Boelhower, (Cambridge 1985), 170.

${ }^{3}$ As will be discussed below, the label 'linguistic turn' can be misleading since it does not 
denote a turn towards the subject of language so much as a methodological perspective deriving originally from structuralist linguistics. The term itself encourages the conflation of the topic of language with the methods of structuralism even before confusing the changes brought about by what has (also inaccurately) come to be known as postmodernism.

${ }^{4}$ Gareth Stedman Jones, Languages of Class: Studies in English Working Class History; 1832-1982 (Cambridge 1983). A review of these debates would require an article in itself. For one overview until 1990, see Geoff Eley, "Is All the World a Text? From Social History to the History of Society Two Decades Later," in Terrence McDonald, ed., The Historic Turn in the Human Sciences (Ann Arbor 1996). More recent interventions include, David Mayfield and Susan Thorne, "Social History and its Discontents: Gareth Stedman Jones and the Politics of Language," Social History 17 (May 1992), 165-88; Bryan Palmer, "The Poverty of Theory Revisited: Or, Critical Theory, Historical Materialism, And the Ostensible End of Marxism,' Left History 1 (Spring 1993), 67-102 James Vernon, "Who's Afraid of the 'Linguistic Turn'? The Politics of Social History and its Discontents,"' Social History 19 (January 1994), 81-97; Marc Steinberg, "Culturally Speaking: Finding a Commons between Post-structuralism and the Thompsonian Perspective," Social History 12 (May 1996), 193-214; and Gareth Stedman Jones, "The Determinist Fix: Some Obstacles to the Further Development of the Linguistic Approach to History in the 1990s," Histony Workshop Journal 42 (1996), 19-35.

${ }_{5}^{5}$ Perry Anderson, In the Tracks of Historical Materialism (London 1983), 44. Anderson's two other unsubstantiated reasons for language's exceptional character are that it changes more slowly over time than other social institutions and that "words are free" and "cost nothing to produce."

${ }^{6}$ Benedict Anderson, Imagined Communities: Reflections on the Origin and Spread of Nationalism, revised edition, (London 1991), 133.

${ }^{7}$ Ferdinand de Saussure, Course in General Linguistics, trans. Roy Harris, (La Salle, Illinois 1986), especially 8-20,65-98.

${ }^{8}$ Bryan Palmer, Descent into Discourse: The Reification of Language and the Writing of Social History (Philadelphia 1990), 9, 14.

${ }^{9}$ Patrick Joyce, Democratic Subjects: The Self and the Social in Nineteenth-Century England (Cambridge 1994).

${ }^{10}$ Antonio Gramsci, Selections from the Prison Notebooks, trans. Quintin Hoare and Geoffrey Nowell Smith, (New York 1971), 440-1.

${ }^{11}$ I take up these epistemological questions in my Ph.D. dissertation currently in progress, "Vernacular Materialism: Antonio Gramsci and the Theory of Language."

${ }^{12}$ While Perry Anderson is the most extreme example, Bryan Palmer and Ellen Meiksins Wood seem to follow his lead in this regard. They both cite favourably the very section where Anderson outlines his view of language. Palmer, Descent into Discourse, 9, 14. Ellen Meiksins Wood, The Retreat from Class: A New 'True' Socialism (London 1986), 77-8. The example of linguistic unification of Italy to be discussed below shows clearly that contra Anderson language is not 'axiomatically individual,' that it can change more quickly than other social institutions and that the cost of its production can be very high.

${ }_{13}^{13}$ Jürgen Habermas, Communication and the Evolution of Society; trans. Thomas McCarthy, (Boston 1979); Jürgen Habermas, The Theory of Communicative Action, 2 vols., trans. Thomas McCarthy, (Boston 1983); Pierre Bourdieu, Language and Symbolic Power, trans. Gino Raymond and Matthew Adamson, (Cambridge 1991).

${ }^{14}$ See Peter Ives, "A Grammatical Introduction to Gramsci's Political Thought," Rethinking Marxism, 10 (1998).

${ }^{15}$ For an interesting interpretation of Saussure that applies greater subtlety to the various contradictions and tensions in his work and argues against the usual interpretation of strong dichotomies of diachronic and synchronic or langue and parole, see Paul Thibault, 


\section{Left History 5.1}

Re-Reading Saussure (London 1997).

${ }^{16}$ This connection can be traced further back not only to George Harris or Luther but also to Dante's De Vulgari Eloquentia (1309?), Marianne Shapiro, De Vulgari Eloquentia: Dante's Book of Exile (Lincoln, Nebraska 1990); see also Umberto Eco, The Search for the Perfect Language, trans. James Fentress, (Oxford 1995).

17 Jonathan Steinberg provides this example and others along with a good discussion of historical changes in the relationship between language and nation. Jonathan Steinberg, "The Historian and the Questione della Lingua," in Peter Burke and Roy Porter, eds., The Social History of Language (Cambridge 1987), 198-209.

${ }^{18}$ This seems to be one of the most important considerations in Mikhail Bakhtin's Rabelais and His World, trans. Hélène Iswolsky, (Bloomington 1984).

${ }^{19}$ For examples of England and Ireland see Tony Crowley, Language in History: Theories and Texts (London 1996); for Italy see Tullio DeMauro, Storia Linguistica dell'Italia Unita (Rome 1986); for France see Eugen Weber, Peasants into Frenchmen: The Modernization of Rural France, 1870-1914 (Stanford 1976).

${ }^{20}$ See Crowley, chapter 4, "Forging the Nation: Language and Cultural Nationalism in Nineteenth-Century Ireland," 99-146.

${ }^{21}$ John Locke, An Essay Concerning Human Understanding (Amherst, New York 1995). In Linguistica ed empirismo nel Seicento inglese (Bari 1970), Lia Formigari argues that Locke's opposition to the conventionalism of previous Aristotelian theories of language was a pivotal point in the recognition of the centrality of language in every process of knowledge.

${ }^{22}$ Hobbes actually argued that the first author of the first speech was God, but that this speech was not copious enough to satisfy all Adam's needs. Adam, adding to this speech especially after the Tower of Babel, was the instigator of the languages that we know today, Thomas Hobbes, Leviathan (London 1985), 100-1.

${ }^{23}$ The question of the relation of the signifier to the signified is often confused with the relation between the sign (the unit made up of the signifier and signified) and the referent (the object to which they refer). Saussure focuses on the signifier/signified relation and says little about the sign/referent relation. While Mayfield and Thorne present an excellent critique of Stedman Jones' use of the theory he presents, they use 'signified' and 'referent' as if they are synonymous. Mayfield and Thorne, 179-81.

${ }^{24}$ Locke, 385-424.

${ }^{25}$ Johann Gottfried Herder, "On the Origin of Language," in On the Origin of Language, trans. John Moran and Alexander Gode, (Chicago 1986).

${ }^{26}$ Lia Formigari, "XIXth- and XXth-Century Philosophical Linguistics," in Tullio DeMauro and Lia Formigari, eds., Italian Studies in Linguistic Historiography' (Münster, Germany 1996), 226.

${ }^{27}$ Humboldt, 42.

${ }^{28}$ Noam Chomsky, Knowledge of Language: Its Nature, Origin and Use (New York 1986), 30 .

${ }^{29}$ One could write a provocative analysis of the use of Gramsci at three levels; the avoidance by political scientists (especially in the English literature) of Gramsci's linguistic thought, the use of Gramsci by British cultural Marxism against structural linguistic oriented French theory and the use of Gramsci by the Italian Communist Party.

${ }^{30}$ Franco LoPiparo, Lingua intellettualli egemonia in Gramsci (Bari 1979).

31 Stedman Jones, Languages of Class, 21-5.

32 Several historians have pointed out the weaknesses in Stedman Jones' actual application of this methodological aim specifically due to his incomplete incorporation of the 'linguistic approach' that he advocates. See Joan W. Scott, Gender and the Politics of History (New York 1988), 53-67, and Mayfield and Thorne.

${ }^{3}$ Ernesto Laclau and Chantal Mouffe, Hegemony and Socialist Strategy: Towards a 
Radical Democratic Politics (London 1985), 65-91.

34 This is what led Gramsci to redefine Vincenzo Cuoco's term 'passive revolution' to mean that there was no active relationship among all the people living in Italy. Gramsci, Selections from the Prison Notebooks, 58-61.

${ }^{35}$ DeMauro, 43.

${ }^{36}$ Gramsci, Selections from Cultural Writings, 26-31.

${ }^{37}$ Ibid., 177.

${ }^{38}$ Ibid., 28.

${ }^{39}$ Ibid., 182.

${ }^{40}$ Gramsci himself stresses the importance of the question whether there has been an Italian romanticism. Ibid., 200.

41 Ibid., 30.

42 Ibid., 183.

${ }^{43}$ Bruno Migliorini, The Italian Language (London 1966), 406.

${ }^{44}$ Gramsci, Selections from Cultural Writings, 28.

${ }^{45}$ Robert Hall, jr. suggests that the solution actually reached should be described not as the soluzione manzoniana but instead the soluzione deamicisiana after Edmondo De Amicis who provided a middle-ground between the classicists and the extreme Manzonian position. Robert Hall, jr., "19th-Century Italian: Manzonian or Deamicisian?" in Paolo Ramat et al. eds., The History of Linguistics in Italy (Amsterdam 1986), 227-36.

${ }^{46}$ LoPiparo, 72-3.

${ }^{47}$ Jacques Derrida, Of Grammatology, trans. Gayatri Chakravorty Spivak, (Baltimore 1976), see especially 167-71, 270-302.

${ }^{48}$ Marc Steinberg, "Culturally Speaking: Finding a Commons between PostStructuralism and the Thompsonian Perspective," Social History 21 (May 1996), 193214.

${ }^{49}$ Gramsci, Selections from Cultural Writings, 124.

${ }^{50}$ It is this idea that has led Luigi Rosiello to compare Gramsci's 'spontaneous' grammar to contemporary linguistic notions of linguistic competence or Chomsky's transformational grammar. See Luigi Rosiello, "Linguistica e marxismo nel pensiero di Antonio Gramsci," in Paolo Ramat et al. eds., Linguistics in Italy', 254, and "Problemi linguistici negli scritti di Gramsci," Gramsci e la cultura contemporanea, vol. 2, ed. Pietro Rossi (Rome 1970), 358.

${ }^{51}$ Gramsci, Selections from Cultural Writings, 180. For a more thorough explanation and a detailed reading of Gramsci's 29th Prison Notebook on grammar, see Ives, "A Grammatical Introduction to Gramsci's Political Thought."

${ }^{52}$ Gramsci, Selections from Cultural Writings, 130.

${ }^{53}$ Gramsci, Selections from the Prison Notebooks, 196.

${ }^{54}$ V.N. Vološinov, Marxism and the Philosophy of Language, trans. Ladislav Matejka and I.R. Titunik, (Cambridge 1986).

s5 Gramsci, Selections from Cultural Writings, 178.

56 The most explicit inability to differentiate Gramsci's various uses of 'hegemony' is Perry Anderson's "The Antinomies of Antonio Gramsci," New Left Review 100 (November 1976-January 1977), 5-79.

${ }^{57}$ Gramsci's distinction between these two processes is similar to that between the creation of traditional intellectuals and organic intellectuals.

${ }^{58}$ Palmer, Descent into Discourse, xiii. 